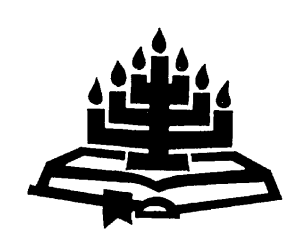

\title{
The trivial round, the common task: minutes of the Missionary Board of the Glasgow Missionary Society (1838-1843)
}

\author{
J.S. Ross \\ Department of Church History and Missiology \\ Dumisani Theological Institute \\ KING WILLIAM'S TOWN \\ E-mail: johnstuartross@gmail.com
}

\begin{abstract}
The trivial round, the common task: minutes of the Missionary Board of the Glasgow Missionary Society (1838-1843)

This article seeks to bring to attention a hitherto little-known account of missionary life among the Xhosa people in the Cape Colony during the period 1838-1843 as contained in "The minute book of the Missionary Board of the Glasgow Missionary Society, adhering to the principles of the Church of Scotland, in Caffraria, and in the neighbouring Colony" (MBGMS). The Missionary Board was responsible for providing adequate material infrastructure and logistical support to enable the accomplishment of the aspirations of the Society. The author argues that such mundane work is often neglected in modern missiological historiography, which focuses rather on the more "spiritual" aspects of mission work. The historiographic approach adopted in this article is that of modern narrative history. By focusing on some of the themes, trends and structures presenting themselves in the record, the MBGMS is permitted to speak for itself with relatively little retrospective interpretation. It is demonstrated that the Board made an important contribution to the achievement of the goals of the Glasgow Missionary Society, as seen in the rise of a Xhosa middle class and the emergence of a significant group of black intellectuals, whose voice and influence are being recovered after years of enforced neglect.
\end{abstract}




\section{Opsomming}

\section{Die onbeduidende omgang, die algemene taak: notule van die Missionêre Raad van die Glasgowse Missionêre Genootskap (1838-1843)}

Hierdie artikel poog om aandag te gee aan die minder bekende feit van sendingwerk onder die Xhosa's in die Kaapkolonie tydens 1838-1843, soos weergegee in "The minute book of the Missionary Board of the Glasgow Missionary Society: adhering to the principles of the Church of Scotland, in Caffraria, and in the neighbouring Colony". Hierdie Raad (MBGMS) was verantwoordelik vir die verskaffing van voldoende infrastruktuur en logistieke ondersteuning om die doelwitte van die sendinggenootskap te verwesenlik. Die skrywer is van mening dat sulke eenvoudige dienswerk al te maklik in die moderne sendinggeskiedenis afgeskeep word, aangesien daar eerder klem gelê word op meer "geestelike" aktiwiteite. Die historiografie in hierdie artikel neem die vorm aan van moderne verhalende geskiedskrywing. Deur aan sommige temas, tendense en strukture in die MBGBS se notules aandag te skenk, word hierdie rekords self aan die woord gestel sodat daar so min as moontlike retrospektiewe interpretasie plaasvind. Daar word aangetoon dat die Raad 'n belangrike bydrae gelewer het tot die verwesenliking van die Glasgow Missionary Society (GMS) se doelwitte - doelwitte soos die tot standkoming van 'n Xhosamiddelklas en 'n betekenisvolle groep swart intellektuele, wie se stem en invloed geleidelik weer hoorbaar word na jare se gedwonge verwaarlosing.

\section{Introduction}

According to St. Paul it would seem axiomatic that "the kingdom of God is not a matter of eating and drinking but of righteousness and peace and joy in the Holy Spirit" (Rom. 14:17). A saying which, on the face of it, might justify a comment made some years ago by a missionary friend who, being responsible for the maintenance of a missionary hospital, lamented that he only ever touched "the outside of holy things". A similar dualistic perspective may be detected in much modern missiological historiography, which tends to focus on the "spiritual" progress of the church, often with relatively little attention being given to the more mundane. But Paul also taught that "whether you eat or drink, or whatever you do, do all to the glory of God" (1 Cor. 10:31). Mundane matters may not so easily be dismissed or denied their contribution to the Kingdom. 
This article, therefore, seeks gently to challenge such neglect and demonstrate from a specific case how much the ordinary, indeed, the almost trivial, has contributed to the growth of the kingdom of God in South Africa. The belief of the Scottish missionaries, that Christ's sovereignty extends over every square inch of creation, to borrow a phrase from Kuyper, led them be diligent in all things, great or small. The pages of The minute book of the Missionary Board of the Glasgow Missionary Society, adhering to the principles of the Church of Scotland, in Caffraria, and in the neighbouring colony (MBGMS) are redolent of this perspective. Whether dealing with horses, oxen and waggons, or buildings, water courses, printing presses, educational supplies and personnel, the Missionary Board discovered that in the ordinary and the mundane as well as in the more obviously spiritual there existed abundant opportunities to "glorify God and enjoy him forever". In the words of the AngloCatholic poet, John Keble, they found that:

The trivial round, the common task

Will furnish all we ought to ask;

Room to deny ourselves, a road

to bring us daily nearer God. (Keble, 1883:3.)

The historiographical approach adopted in this article, therefore, is essentially that of modern narrative history. By focusing on some of the themes, trends and structures presenting themselves in the record, the MBGMS is permitted to speak for itself with relatively little retrospective interpretation. The article seeks first to establish the milieu of the work of the missionaries recorded through the MBGMS. This requires brief consideration of contemporary events in Scotland, the Cape Colony and, what was termed, British Kaffraria, being the territory bounded first by the Keiskamma river and then by the Kei river in which the missionaries operated. 1 This necessarily includes consideration of the formation of the mission itself and its interaction with the amaXhosa nation during a very unsettled period of colonial history. 2 Secondly, against this background the work of the Missionary Board of the Glasgow Missionary Society (GMS) is seen for what it was, the struggle to provide an adequate material

1 Over time the borders and nomenclature of British Kaffraria changed. During the period under consideration, 1838-1843, the border was drawn at the Keiskamma river and the territory known as Province of Queen Adelaide, the earlier boundary had been fixed at the Great Fish river east of Grahamstown. 
infrastructure to enable the accomplishment of the aspirations of the society as envisioned in its 1841 annual report.

A hundred years hence Kaffreland $\mathbf{3}$ will be a Christian country, and the Lovedale Institution, or some other to which it may give rise, will be sending forth its hundreds ... of messengers of the cross, eastwards and northwards, into countries of which we know not as yet even the name. (Shepherd, s.a., xv.)

Finally, a summary discussion shows how the missionaries' endeavours achieved the society's goals and led to the creation of a Xhosa Christian middleclass who made a significant contribution to the lives of their own people, as well as to the wider South African community and beyond. The article confines itself to entries in the Minute book for the period from 1838 to 1843, the year of the disruption of the Church of Scotland and the formation of the Free Church of Scotland, to which most of the missionaries adhered; the remaining missionaries associating themselves from 1847 with the United Presbyterian Church. 4

\section{The Glasgow Missionary Society in British Kaffraria}

\subsection{The establishment of the Mission on the Tyume ${ }^{5}$}

In 1816, the missionaries Joseph Williams and James Read of the London Missionary Society led their little party, including John Tshatshu, a young Xhosa chief, and their Khoikhoi attendants into this unsettled region. Ngqika cordially invited them to settle on the banks of the river Tyume, close to his Great Place at the western end of the Amathole mountains. Ngqika's policy in accommodating the missionary settlement was in essence similar to that of Lord Charles Somerset, Governor at the Cape. Ngqika believed Xhosa

3 Spellings of Kaffreland and Kaffraria differ considerably; citations follow original spelling.

4 The interdenominational Glasgow Missionary Society was formed in 1795 , drawing support from the Church of Scotland, the Secession synod (1733) and the Relief synod (1761). In 1820 majorities from all factions of the secession reunited as the United Associate Synod of the Secession Church. In 1843 the Free Church of Scotland was formed by secession from the Church of Scotland. In 1847 the Secession Church and the Relief Synod united to form the United Presbyterian Church. A convenient way to track the complex structure of Scottish Presbyterianism is through the fold out chart in Burleigh (1960).

5 Spellings include Tyhume, Chume, Chumie; recent cartography prefers Tyume which is used here. 
security would be enhanced by the settlement of missionaries who might act as intermediaries between the Xhosa and the Governor, whilst the Governor saw missionaries as a willing source of intelligence and influence, operating as they did beyond the bounds of his jurisdiction and living close to Ngqika, whom Somerset had recognised as the principal chief. The consequence for the missionnaries was that they were never fully trusted nor respected by either side.

Mrs. Williams has left on record the personal hostility she and her husband faced as they passed through colonial communities on their way east, being repeatedly told that "nothing but powder and ball would suffice to bring the [Xhosa] to their senses and that only 'after they [the border residents] had sent a good lot of them to hell' would the time arrive for preaching salvation to them" (Shepherd s.a.:16).

Williams' successor at Tyume was John Brownlee, who arrived at the Cape as a missionary of the London Missionary Society in 1816. The GMS station established at Tyume in 1826 by John Ross and John Bennie was effectively an outgrowth of Brownlee's work. When Ross arrived at the Cape of Good Hope on 4 September 1823, he met John Brownlee, then a government missionary, who had been recuperating from serious illness and agreed to travel with him and Mrs. Brownlee by land to Tyume. John Bennie wrote to Rev. John Love, secretary of the GMS, 20 December 1823, telling how he had met the Brownlees and the Rosses some miles west of Grahamstown.

$\mathrm{Mr}$ and Mrs Ross, accompanied by $\mathrm{Mr}$ and Mrs Brownlee, arrived here in health and safety, on 16th instant. Being a little indisposed for some time, [and] having rode down to Graham's Town, to purchase a few articles, I saw a letter from Mr R. and a waggon load of his goods. Concluding he must be near, I went forward and on 11th at sunrise, I met the waggons 22 miles from the Town. Mr and Mrs Thompson met us 15 miles from the [Lovedale] Institution, with a body of the people mounted on pack oxen. On our reaching the Institution we assembled in $\mathrm{Mr}$ Brownlee's house, and thanked our God for the mercy and goodness he had manifested towards us. (GMS report:1824.)

Ross had brought with him from Scotland a printing press and little time was lost in setting it up.

Having arrived on 16th December, 1823, on the 17th we got our Press in order; and on the 18th the alphabet was set up; and yesterday we threw 
off 50 copies. ... Through your instrumentality a new era has commenced in the history of the [Xhosa] nation. (GMS report:1824.)

John Bennie, the Scottish-born linguist, joined the GMS in 1816, when he was just twenty years old. Cutting short his studies he sailed to the Cape in 1821 in the ship Woodlark which was bringing supplies for the settlers. Arriving with William Ritchie Thomson, he joined Brownlee and his wife at Tyume. In November 1821 he opened a school and started an intensive study of isiXhosa. In November 1824 he and Ross founded the adjacent station of Ncera, which two years later was renamed Lovedale, after the GMS secretary.

In 1826 Bennie wrote $A$ systematic vocabulary of the Kaffrarian language and An introduction to Kaffrarian grammar, the first of several landmarks in grammatical and lexical work that laid the foundation for the translation of the Bible into isiXhosa. He was ordained in 1831 by the first presbytery of Kaffraria, moving to Burnshill in 1843. The Seventh Frontier War (1846-1847) forced a further move west to the Karoo town of Graaff-Reinet, where he served as a missionary in the Dutch Reformed Church.

\subsection{The amaXhosa and the wars of dispossession}

In modern anthropological usage, the term Xhosa refers to the Southern or Cape Nguni people in general and strictly speaking designates a linguistic, rather than an ethnic, category. Currently historians favour the idea of a progressive southwards trek of the Nguni from Central Africa, arriving in the Cape perhaps only five or six centuries ago. By the time of the first missionaries in the region, the early 1800s, the main Xhosa groups were the amaGcaleka inhabiting the Amathole mountains; the amaRharhabe who made their home in the vast territory stretching from the Great Kei river in the east to the Gamtoos river in the west; the Gqunukwebe, who had intermarried with Khoikhoi and occupied the coastal area between the Chalumna and Kwelera rivers; and the Ndlambe, who had settled between the upper Gonubie and Buffalo rivers.

In 1702 a meeting between European traders from Stellenbosch and a party of Xhosa from the area of the Great Fish river broke up with shots being fired and assegais thrown, ushering in almost two hundred years of conflict over the highly prized, well watered pastures of the land of the Xhosa. Between 1779 and 1877, successive colonial administrations engaged in nine frontier wars, the cumulative effect of which was the dispossession of the Xhosa 
of both their land and their sovereignty. The range of colonial policies applied included the annexation of land; the expulsion of the Xhosa from areas once in their possession; and the imposition of a "neutral" buffer zone between the Great Fish and Keiskamma rivers. In addition, the British sometimes favoured the policy of indirect rule through Xhosa chiefs by means of treaties, often deliberately undermined by attempts to "divide and conquer", and finally abandoned by the obstreperous Sir Harry Smith on his becoming Governor of Cape Colony in 1847. Smith annexed a huge swathe of Xhosa territory lying between the Great Fish and Kei rivers, reducing the Xhosa chiefs to little more than government agents operating under British law administered by local magistrates. The most hotly disputed territory, lying between the Great Fish and Keiskamma rivers, became known as British Kaffraria and was the location for the work of, among others, the Scottish missionaries of the Glasgow Missionary Society (GMS).

Ngqika, on whose land the Scottish missionaries came to settle, was a young Xhosa chief determined to assert himself against his uncle Ndlambe, who, together with the paramount chief, Hintsa, had humiliated him in a number of skirmishes between their warriors. Ngqika's defeat in 1818 by Ndlambe and Hintsa at the battle of Amalinde, near Debe Nek, gave the British an opportunity to further diminish the Xhosa. Anxious not to escalate the tension between himself and the British, Ndlambe send word to the Colony rejecting Ngqika's claim to be king, but assuring the colonists he wished to remain at peace with them. The British, however, chose to interpret events differently, arguing that Ndlambe's quarrel with Ngqika was related to Ngqika's pro-British attempt to repress cattle raiding. In December 1818 the fifth Frontier War opened when under the pretext of coming to the assistance of their ally Ngqika, two large commandos entered Xhosa territory and drove off some 23000 cattle. Andries Stockenstrom, who himself led one of the commandos, considered that the Government had deliberately interfered "in a quarrel that did not concern us", adding that they "took from a vast population the flocks upon which they, men women and children were exclusively dependent for their very existence" (Majeke; 1952). The Xhosa were devastated by the British policy of total war, so different from their own low casualty skirmishes that were more intended to punish their enemies by the removal of a few cattle than to cause wholesale destruction. The destruction of standing corn, the burning of homes and the large scale expropriation of cattle condemned the Xhosa to impending starvation. As one Xhosa councillor put it: 
You sent a commando - you took our last cow - you left only a few calves which died for want, along with our children. You gave half the spoil to Gaika; half you kept yourselves. Without milk - our corn destroyed - we saw our wives and children perish - we saw that we must ourselves perish; we followed therefore the tracks of our cattle into the colony. (Peires, 1981:79.)

It was enough for Ndlambe that the spoor of many of the captured cattle led directly to the small settlement Grahamstown and his ensuing bold daylight attack on March 1819 might well have succeeded if it was not for the superior firepower of the British, forcing the Xhosa still further eastwards, beyond the Keiskamma river (Milton, 1983:69 ff.).

The period recorded by the Minute book follows on immediately from the sixth Frontier War (1834-1835), during which the first Lovedale was destroyed by Xhosa action and rebuilt in 1836 on the western bank of the Tyume. 6

\subsection{The Missionary Board}

The Minute book of the Missionary Board of the Glasgow Missionary Society, adhering to the principles of the Church of Scotland, in Caffraria, and in the neighbouring colony, for the period 20 June 1838 to 4 October 1865, held in the collection of the Amathole Museum, King William's Town, provides the historian with valuable insights into the day to day operations of the early Scottish missionaries among the Xhosa people.

In Scottish presbyterianism, the spiritual oversight of the church falls on those elected as elders, who along with ministers, form the church courts of kirk session, presbytery, synod and general assembly. The material and financial responsibilities are allocated to the deacons' court which consists of both elders and deacons. The spiritual work of the missionaries was supervised by the first Presbytery of Kaffraria, with the Missionary Board being the counterpart of a deacons' court and therefore consisting of the "ministers,

6 I am grateful to Stephanie Victor, Curator of History, Amathole Museum, for the information that the cast iron Ruthven Press used by Ross and Bennie, although badly damaged when the mission was burnt down, is now on display in the Missionary Museum, King William's Town. Its accessories and type have, however, disappeared - the tin/lead alloy used for type makes excellent musket balls! 
preachers, catechists, and mechanics" in connection with the GMS. The ministerial missionaries were the Revs. John Ross, John Bennie, James Laing and William Govan, and the "mechanics", Alexander MacDiarmid and James Weir. The Board was under the jurisdiction of the Presbytery and responsible, "subject to the approval of the Directors" for the "direction, superintendence, and management of the secular concerns of the GMS adhering to the principles of the Church of Scotland, in Caffraria, and in the neighbouring Colony".

The Board's authority included oversight of the missionary salaries and locally incurred expenses, for which the missionaries were required to keep a "regular account of their work, and of whatever work is going on under their management, or oversight" (MBGMS:i). Each missionary on arriving in the Cape Colony was permitted to draw in advance their first year's salary and instructed when in transit "to provide decent and comfortable lodgings for themselves, and proper means of conveyance to the missionary station". These, as well as any other expenses incurred on disembarkation in South Africa were chargeable to the Society. For settled missionaries, other refundable expenses included travelling costs incurred by necessary absence from home in pursuit of their work, appropriate medical advice and medicines, and the funeral expenses of any missionary dying in Africa, or of his wife and children, "presuming these to be moderate" (MBGMS:ii). Temporary repatriation to Scotland, in the event of serious illness, and on the advice of a qualified medical practitioner, could also be a charge upon the society; as could be the expenses of a travelling companion, providing that such "may be reckoned indispensably necessary" (MBGMS:v). Costs for the erection of ancillary buildings, necessary for a missionary's work, could be recouped, as also could the "salaries of native teachers, postages, packets and other incidental expenses". In general, building expenses were regulated by a broad interpretation of the "spirit of the instructions sent out from time to time by the Directors" but if any expense greater than $£ 70$ was incurred "the consent of the Directors shall first be asked and obtained". Each November stipends and expenses were drawn by the missionaries; the treasurer being instructed not to authorise any bills unless approved by the Board.

\section{The reconstitution of the Glasgow Missionary Society}

A decision was taken at a meeting at Lovedale on 17 May 1838 to dissolve the original Board and reconstitute it to more accurately reflect ecclesiastical loyalties in Scotland concerning the issues of es- 
tablishment and voluntarism, in the period that has become known as the "Ten Year's Conflict", leading up to the events of 1843 and the formation of the Free Church of Scotland. Consequently, on 24 July, after the minutes of the previous meeting had been read and approved, the meeting was promptly closed with prayer and the new Board constituted (MBGMS:3). All the missionaries with the exception of Chalmers and Niven associated themselves with the "missionary Board of the GMS adhering to the principles of the Church of Scotland, according to the rules of the former Board". Chalmers and Niven decided to join the "voluntary" Glasgow South African Missionary Society. 7 To the first group, consisting of Bennie, Ross, MacDiarmid, Laing and Weir, went the stations of Lovedale, Pirie and Burnshill; with the stations at Chumie and Qhibira being made over to Chalmers and Niven. Whilst in Scotland the "Ten Year's Conflict" was protracted, bitter and rancorous, it was not so in South Africa. As denominational difference made little or no difference to missionary policy, the missionaries had agreed that their personal scruples must not to be permitted detrimentally to affect their work, witness or personal relationships. According to Laing's Memorial, "All risk of imprudent excitement to the Natives generally is averted by our unanimous determination to avoid the slightest allusion to the separation - and to pursue our work as if the event had never occurred" (Shepherd, s.a:92). Thus in a rather bizarre and yet peculiarly Scottish manner, conscience was honoured by separation made on a matter of principle, or at least strong opinion, but otherwise everything proceeded as hitherto, without the outside world being unaware of the ecclesiological differences between the missionaries. Remarkably, although two Boards were formed from this date they both continued united under a single Presbytery until 1842. In 1843 the majority of missionaries joined the Free Church of Scotland, and in 1847 the Glasgow South African Missionary Society came under the jurisdiction of the United Presbyterian Church. None of these organisational changes resulted in the adoption of different policies regarding the South African mission.

7 The ecclesiological difference between the missionaries, and their home churches, centred around the question of the legitimacy, or otherwise, of the establishment principle. Those who adhered to "the principles of the Church of Scotland" believed in a State church, those, like Chalmers and Niven who disagreed were referred to as "voluntaries". 


\section{The Minute book}

\subsection{Waggons, oxen and horses}

At a meeting held on 24 July 1838, Laing had requested the directors to permit him to purchase a horse, "as the horse now in his possession was incapable of performing the work which was required". As a supporter of the work, R. Williams Esq. had left $£ 6$ for the purchase of a horse, Laing offered to trade in his current mount and, adding the $£ 6$, would, if permission were granted, purchase a more serviceable beast (MBGMS:5). At the same meeting, MacDiarmid and Weir were "appointed a committee to examine the state of Lovedale and Pirie waggons" and the clerk has to write to "a friend in the Colony concerning a good second-hand waggon for the use of the station which we are about to form" (MBGMS:6). The committee later reported that they recommended the Pirie waggon to be repaired but considered the Lovedale waggon irreparable. Ross, who depended on the use of the Pirie waggon, had, however, taken the initiative and had got it repaired (MBGMS:8). The "friend in the Colony", to whom the clerk had written, turned out to be a "tradesman" who had in stock both new and used waggons, which, it was agreed, could be considered at the next meeting. The minutes of the meeting held on 3 January 1839, however, record that "Mr. Bennie stated he had purchased a good waggon, complete for $£ 60$, and that Mr. Weir informed the meeting he was making inquiry for a new waggon and a span of oxen". On 2 April 1840 the Board instructed the clerk to write to the directors "concerning an additional horse for Mr. Weir, and an allowance to meet the expense of transporting provisions to the distant station, and of some other incidents peculiar to it. $£ 8$ sterling was proposed as a sum to be given to the missionaries resident at that station" (MBGMS:29). On 8 April 1841 Mr. Bennie informed the Board that a "Mr C.B. Zleivogel had presented a horse to the Society" (MBGMS:45).

\subsection{Weir's new station}

In the winter (June/July) of 1838, Weir and Laing, who had been commissioned by the Presbytery to survey the area with a view of establishing new mission stations, were encouraged by the directors in Scotland to take into consideration the area around the headwaters of the Keiskamma river (MBGMS:6). On 8 May 1839, "Mr Weir requested that one of the brethren do accompany him to the field which had been selected by the Presbytery as a sphere for missionary operation, to aid him in ... the erection of the mission premises" (MBGMS:14). As an epidemic of measles had broken out 
on the frontier, the Board instructed Laing to cooperate with Weir in securing help, if necessary, from as far away as Grahamstown. At the meeting of 25 July 1839, further cryptic reference was made by Mr. Laing about a visit to "the field to which Mr Weir had been appointed and that conjointly they had fixed on a site for the mission premises, under very favourable circumstances" (MBGMS:17). Curiously, at this point the minutes contain no information of location of the new mission station. By July 1840 the decision was taken to excuse Weir from attendance of any "emergency" meetings of the Board "on account of the distance" (MBGMS:33). And, when in 1840/1841 he was appointed President of the Board, most minutes for that year state, "The meeting was opened in prayer by [name], in the absence of Mr Weir, President". By April 1842 it becomes clear that the new station was not near the Keiskamma but located some 65 miles east of Lovedale on the river Kwelehra, north-west of the modern East London, in the territory of Umhala, son of Ndlambe, who had succeeded his father as chief in 1828. At the meeting of 3 January 1842, there was a discussion regarding an interpreter and "native assistant" at Kwelehra (MBGMS:53). By the middle of the year, however, the decision was taken that the experiment should be terminated. On account of the opposition of Chief Umhala "it had become advisable to remove Mr. Weir from Kwelehra, it was agreed that all the Society's waggons should be sent thither to aid in his removal" (MBGMS:55). 8 Notwithstanding any local opposition experienced, Weir and his wife had also suffered the loss of a son at Kwelehra. In March 1841, the Grahams Town journal carried the following announcement: "Died at Kwelehra, Kafirland on 8th February, James, son of James WEIR, Missionary, aged 3 years and 4 months" (Mackay, S., 1841).

\subsection{Measles, life insurance, "savage violence" and small pox}

In May 1839 the political instability of the region and a threat of a measles epidemic combined to increase the missionaries' sense of vulnerability. The Board, therefore, instructed the clerk "to write to a friend in Cape Town for information as to whether or not the insurance society there would be willing to insure the lives of missionaries in Kafferland and the rate of premium required" (MBGMS:13). Shortly thereafter, measles did arrive in the mountains and valleys of the Amathole district; many Xhosa people fell ill, as did members of the missionary families and to prevent spreading the contagion the

8 For Umhala's comments see Maclean (1866:20). 
Board meeting for early July was cancelled. A letter from Rev. Dr. Adamson, Cape Town was read at the meeting of the 3 October, indicating the following:

Assurance Societies in Cape Town are not agreed as to the propriety of assuring the lives of missionaries in Kafferland unless their liability cease in the event of 'death by savage violence'. (MBGMS:20.)

Thus on 7 November, it was again agreed to request the clerk to make enquires of the

... G. Town Insurance Society with respect to their conditions of insurance, and if he find them favourable to state to them that each of the missionaries of our body will insure his life for $£ 500$, agreeably to the letter on the subject which we have received from the Directors. It was understood that if arrangements should be made in Graham's Town for insurance that the Board would draw on the Directors in the course of the year for the premium required for $£ 500$. (MBGMS:25.)

By January 1840, it transpired that two of the missionaries who had been in Grahamstown had discussed insurance with "several gentlemen officially connected with insurance Societies" but had been disappointed to learn "that there was no certainty afforded that these societies would receive applications from Kafferland, but that if they should, the premium would be ... more in Kafferland than in the Colony" (MBGMS:27). The matter remained unresolved throughout 1840 and despairing of finding a solution to their problem in South Africa the missionaries agreed to put the directors in Scotland

... in possession of the correspondence with the Graham's Town Assurance Company and of such other requisite information as we can supply that should they deem it advisable to insure our lives in Britain rather than in the Colony they may, without further delay, have it in their power to do so (MBGMS:32).

A further health scare ensued when "the messenger sent to call [Rev. John Ross of Pirie, to a meeting on 9th September, 1841] had been made to turn back on the way in consequence of a precautionary measure which the chief had taken to prevent the spread of the small pox" (MBGMS:50). Then, two and a half years after the matter had first been raised, a letter from the directors, read at the meeting of 7 October 1841, contained the welcome information 
... that the Directors have insured $£ 500$ on the life of each of the brethren (except Mr Govan whose life had been insured before) as a provision for widows and orphans, the meeting expressed their sense of gratitude to the Directors for the provision which they had thus made, \& instructed the Clerk to convey their grateful acknowledgment to them (MBGMS:50).

\subsection{The Seminary}

From the inception of the work, the missionaries had been concerned to establish a school both for their own children and those of the surrounding Xhosa. In July 1839 the Board agreed to write to the Glasgow directors to ask them to state that "in the event of no suitable individual being found to act as a tutor in the [proposed] Seminary, whether or not the missionaries would be at liberty to send their children to the Colony for education, at the expense of the Society with the undertaking that each missionary shall not send more than two children at a time" (MBGMS:18). A tutor, however, was found and at the meeting of 8 October 1840, the imminent arrival in Algoa Bay (Port Elizabeth) of Rev. William Govan was intimated and the decision taken to send John Ross to "conduct him to Kafferland and that he be authorised to make all requisite preparations for the journey" (MBGMS:35). At the meeting of $7 \mathrm{Ja}$ nuary 1841

Mr Ross reported that according to appointment, he had gone to Algoa Bay to meet Mr and Mrs Govan, and that he had conveyed them to Lovedale on 16th inst - Mr Ross then introduced Mr Govan to the meeting, and proposed that he should be admitted a member of the Board, which was unanimously agreed to. Messrs Bennie, Govan and MacDiarmid were appointed a committee to make all necessary arrangements preparatory to the opening of the Seminary - Mr. Bennie to be convener. (MBGMS:40.)

They also agreed that "D.V. a meeting be held at New Lovedale, inter alia to receive Rev. W. Govan on his arrival at that station" (MBGMS:39). On 8 March 1841 the Board agreed to open the Seminary on Thursday, 8 April, and to invite Rev. William Ritchie Thomson to preach (MBGMS:42). Thomson, the friend of Bennie, now a government missionary, was the first ordained GMS missionary in South Africa, and had three years earlier presented the Voortrekker, Jacobus Uys, with the gift of a Bible on his departure into the interior. In the event, however, the building work remained unfinished and the ceremony was postponed. The opening took place on 21 July 1841. Thomson preached, and after worship presided over the opening meeting which was addressed by "several of 
the brethren" including Rev. H. Calderwood and Rev. Mr. Birt of the London Missionary Society. "The Rev. Mr. Bennie gave a short outline of the speeches in the [Xhosa] language." (MBGMS:48.)

In the evening applications were made for admission into the Seminary by 9 boys of European parentage, and 10 native youths who were respectively examined as to their qualifications. On the following morning ... another meeting was held at which the pupils were addressed by a number of friends present on their duties and privileges as students in the Institution. The Rev. Mr. Kayser of the London Miss. Soc. Addressed the native pupils in the [Xhosa] language. A native boy having made application for admission was examined as to his progress in education. The members of the Board ... considered the claims of the above applicants, when it was agreed the whole be admitted to attend the classes. (MBGMS:48.)

Further applications came in from other churches and mission stations, including one from a person called Banyane, from John Brownlee's church. The Board agreed to admit these students, equip them with books but require them to make their own provision for board and clothing (MBGMS:56). From the very outset, Govan determined Lovedale would be non-denominational and multiracial, with all being accorded all the rights of British subjects (Shepherd, s.a.:98).

The saga of the erection of the seminary buildings revolves largely around the activities of Bennie and MacDiarmid who in 1839 were appointed "a committee to superintend the operations of erecting the building of the Seminary and in the meantime ... instructed to purchase wood, and to endeavour to make an agreement with a mason for the building of the walls" (MBGMS:18). MacDiarmid presented plans to the meeting of 22 August 1839 for a house for the tutor, " $54 \frac{1}{2} \mathrm{ft}$ by 26 , over all, which was approved" (MBGMS:19). By 3 October Bennie and MacDiarmid reported "they had engaged Jacob Trollip a mason, to erect the house of the tutor, that he was expected to begin to build next week, and that parties of natives have been for some time employed in quarrying stones and conveying them to the site of the buildings" (MBGMS:20).

The Board, meeting at Lovedale, "resolved itself into a committee for the purpose of examining on the spot how much arable land may be obtained for the Seminary, when it found that from 40 to 50 acres of good land may be obtained under the level of the water course 
which has already been commenced" (MBGMS:21). ${ }^{9}$ Returning to their room, they agreed to write to the directors "for a supply of such articles as are required for the use of the house of the Tutor and buildings connected therewith" (MBGMS:21). The meeting of 6 November convened to present the accounts of 1839, "agreed that $£ 250.0$.0 should be drawn for carrying on the buildings of the Seminary" (MBGMS:23). By 6 May 1840 the building of the Seminary was progressing satisfactorily. It was agreed a further $£ 100$ was to be drawn

... for the accommodation of native students, as the Directors have resolved to endeavour to send out a Female Teacher, it was agreed that the Committee for the Seminary be authorized to erect two wings to the building now in progress, each wing to be about fifteen feet in breadth, the one for the lodging of native pupils and the other for a school room for the female Teacher (MBGMS:30).

In July 1840 a further $£ 100$ withdrawal was authorised, but the minutes of 8 October state that the clerk drew $£ 150$ (MBGMS:34). Yet another $£ 100$ was authorised on the 27 August meeting (MBGMS: 35). By this time a sum in excess of $£ 450$ had been expended and the buildings were still not yet completed. By November all budgetary restraint seems to have been abandoned, and it was suggested that an additional $£ 200$ was "at present required for said Institution, but the further examining of the account was delayed until the buildings now being erected be completed" (MBGMS:37).

As late as April 1841, even as the Board were planning the inauguration of the Seminary and the installation of its first principal, it agreed to yet further buildings being erected: a class room measureing 25x17 ft. for Mr Govan, a small room adjacent for a library, and a further small room and class room for the "Female Teacher". Domestic arrangements included the building of a kitchen measuring $21 \times 13^{1 / 2} \mathrm{ft}$. above which would be two rooms for the accommodation of servants. To cover these costs a further $£ 150$ be drawn, plus $£ 30$ for purchasing provisions (MBGMS:45). The meeting of 22 July 1841 approved the expenditure of an additional $£ 100$ "for the buildings of the Seminary before the end of the Quarter" and on 9 Sep-

9 The topography is clearly illustrated on the map: sketch of the lands of the property of the Free Church and Charles Stretch as grant appeared when Caffraria was invaded by British forces on 9 April 1846 (Cory Library, Rhodes University, Grahamstown). 
tember 1841 another $£ 100$ was authorised (MBGMS:50). The principle buildings were declared to be completed at a meeting of the Board on 7 April 1842 and Bennie and MacDiarmid were to present their final report before the next meeting.

\subsection{The irrigation channel}

Adjacent to Lovedale was the residence of Captain Charles Lennox Stretch, the British government commissioner to Ngqika's people, known to the Xhosa as Xol'ilizwe (the Peace-maker) and to the missionaries as "the philanthropic commissioner". On his land Stretch had begun to open up what are considered to be some of the very first irrigation systems in South Africa. At the meeting of 3 October 1839

Mr Bennie stated that Cap. Stretch had made a proposal to him to the effect that he would continue the work of cutting the water course from the Chumie for the irrigation of his own grounds and those of the Seminary, on the condition that the Board should bear the half of the expense. The Board agreed to this proposal, provided our share of the expense should not exceed $£ 100$. (MBGMS:21.)

On 22 July 1841 a letter from Captain Stretch was received requesting "pecuniary assistance in cutting the water-course". It was agreed to adjourn the meeting until the next day and that "the members of the Board proceed at sun-rise to the water-course and examine the state of the work there, and that afterwards they confer with Mr. Stretch and make such arrangements as they shall deem necessary" (MBGMS:49). A marvellously complete, yet, succinct minute recorded that on 23 July

... the members of the Board proceeded at sun-rise to the water-course, inspected the work performed, conferred with $\mathrm{Mr}$ Stretch, returned to Lovedale, took into consideration the state of the work in cutting the water-course, and agreed to draw $£ 50$ for that object, on the understanding that that sum is all that the Board will be called on to expend on that work (MBGMS:49).

\section{On 24 December 1841}

[t]he Board had a conversation with Cap. Stretch regarding the manner in which the water-course is to be kept in repair, and he agreed to draw up a plan on the subject and to lay it before the Board at the meeting in January. Cap. S. also gave in an Abstract of the receipts and expenditure for the water-course. He promised to prepare for the mission a diagram of the lands 
connected with the Residency, Lovedale station and the Seminary - it was agreed that $£ 88$ be drawn on account of the Seminary, and that $£ 12$ be drawn for the water-course. (MBGMS:52.)

\section{At Lovedale on 4 January 1842}

... [t]he Abstract of the Receipts and Expenditure for the watercourse which Mr Stretch had given in to the meeting on 24 ult. was considered, from which it appeared that the receipts for the water-course amounted to $£ 358$, and the expenditure £434.9.9. It was agreed that the Clerk write to Mr Stretch and state to him that the Board do not feel authorized to advance any more money for defraying the expense of the water-course above the Church.

By 10 March it was evident that a serious and strong difference of opinion had arisen between Stretch and the Board concerning the funding and therefore their entitlement to use the irrigation system. Stretch attempted, honourably, to get the Board to match his contribution and so increase their use of the water. The Board, however, declined and tensions escalated, with the Board adopting the following litigious resolution:

That acting as they do in this affair not in a private but a public capacity they cannot possibly allow it to rest in the present position: that however reluctant they are to bring such a matter before the public, the tone of the last communications from $\mathrm{Mr}$ Stretch leave little room for hope that it will be possible to avoid such a course, but that in the meantime the Clerk be instructed to write to Mr Stretch proposing an amicable adjustment of the matter in dispute between him and the Board by reference to two or more individuals mutually agreed upon by the parties. It was then agreed that a committee be appointed to carry out the above resolution ... viz. Bennie, MacDiarmid, Laing and Govan. (MBGMS:56.)

At the meeting of 16 June Govan reported verbally that Captain Stretch had agreed that the dispute be settled by arbitration and had invited Rev. James Read, junior to represent his interests. The committee had prevailed on Rev. John Brownlee to act for the Board. All the preliminary arrangements had been completed with Captain Stretch; the Board had placed in the hands of Mr. Brownlee a detailed report of the points at dispute, and the arbiters had appointed a day for a meeting at which their decision would be given. At this point John Bennie took it "upon himself to urge on Mr Stretch the duty of attempting to effect a reconciliation between him and the 
missionaries of the Board". Stretch had "fully acquiesced in this suggestion" and indicated his readiness to do all within his power to resolve the outstanding differences. Bennie consulted with Weir and Govan before indicating to Stretch the terms on which he believed the Board would make an agreement. Stretch had no difficulty in acceding to these terms. The "soft word" from Bennie had effectively brought the matter to a satisfactory conclusion and the Board unanimously approved of his initiative. The next day Bennie and MacDiarmid reported that they had met with Stretch and found "that gentleman most ready to accede to the terms alluded to ... and that at his request they had prepared a written agreement two copies of which were signed by Mr Stretch and the Committee" on behalf of the Board (MBGMS:59). Much to everyone's gratification the dispute had been resolved honourably and to their entire satisfaction.

\section{Conclusion}

The diligence of the Scottish missionaries in "little" things, as well as their readiness to face hardship and accept personal sacrifice, paved the way for the realisation of the hopes of the founders of the mission and more: the establishment of a Xhosa church, the flowering of Lovedale Missionary Institution, the planting of the Presbyterian Church in Malawi by Xhosa and Scottish missionaries, and the rise in the late nineteenth century of a Xhosa Christian intelligentsia. This group included such luminaries as Tiyo Soga, the first Xhosa Christian minister, and his Scottish educated son, the missionary ethnologist Dr. John Henderson Soga, the poet John Knox Bokwe, writer and minister Isaac Williams Wauchope, John Tengo Jabavu, the founder of South Africa's first black newspaper, Imvo Zabantsundu, and his son, Professor Davidson Don Tengo Jabavu, the first black academic at the University of Fort Hare. Gwayi Tyamzashe, William Wellington Gqoba, Elijah Makiwane, Walter B. Rubusana, and Pambani Jeremiah Mzimba were also prominent in this Xhosa renascence.

Bokwe's son-in-law, the educationalist, church leader and African nationalist, Z.K. Matthews once described them all as "leaders [who] drank deep at the spring of western civilisation and yet ... remained true Africans, loyal to the best traditions of their people and good examples of what has been described as the African personality" (Matthews, 1961). Cruelly deprived of their voice for most of the twentieth century, these eminent Christians, who grappled bravely with the challenges of modernity and black identity in a colonial society, merit a fresh and careful hearing. Thankfully, through the repu- 
blishing of their literary legacy their voice is being heard once more at a crucial juncture in South African history. 10 In addition, we can be grateful for the emergence of a better balanced and more finely nuanced, though not uncritical, assessment of British colonial policy, the missionary contribution and the influence of African Christian intellectuals. Recently, Dr. Mcebisi Ndletyana has argued that "these early intellectuals, based in the Cape, owe their rise to the cumulative impact of missionary activities, as well as to British colonialism". Adding that the common objective of both was "to create an indigenous middle class that would share the value systems and economic interests of the settler community" (Ndletyana, 2008:1 ff.). To the achievement of this goal the Missionary Board of the Glasgow Missionary Society made its own significant contribution.

\section{List of references}

ANON. 1824. Glasgow missionary society annual report.

BALKEMA, A.A., OPLAND, J. \& NYAMENDE, A., eds. 2008. Isaac Williams Wauchope: selected writings, 1874-1916. Cape Town: Van Riebeeck Society.

BURLEIGH, J.H.S. 1960. A church history of Scotland. London: Oxford University Press.

CORY LIBRARY FOR HISTORICAL RESEARCH. s.a. Plans of the ground in the neighbourhood of Block Drift near the Chumie River in British Kaffirland. Grahamstown: Rhodes University. (Ref. M77 / F2.)

CORY LIBRARY FOR HISTORICAL RESEARCH. 1846. Sketch of the lands of the property of the Free Church and Charles Stretch as grant appeared when Caffraria was invaded by British forces on 9th of April 1846. Grahamstown: Rhodes University. (Ref. M77 / F2.)

GLASGOW MISSIONARY SOCIETY. Missionary Board. 1838-1865. The Minute Book of the Missionary Board of the Glasgow Missionary Society, adhering to the principles of the Church of Scotland, in Caffraia, and in the neighbouring Colony: 1838-1865. King William's Town: Amathole Museum.

GMS

see ANON. 1824.

KEBLE, J. 1883. The Christian year: thoughts in verse for the Sundays and holy days throughout the year. London: Rivington.

MACKAY, S. 1841. Grahams Town journal: CO53/14 National Archives. Kew, London. http://www.genealogyworld.net/settlers/journal_35.html Date of access: 5 Feb. 2009.

MACLEAN, C. 1866. Compendium of kafir laws and customs. Cape Town: Saul Solomon. 
MAJEKE, N. 1952. The role of the missionaries in conquest. Johannesburg: APDUSA.

MATTHEWS, Z.K. 1961. Rev. John Knox Bokwe. Imvo Zabantsundu, 5 Aug.

MBGMS

see GLASGOW MISSIONARY SOCIETY

MILTON, J. 1983. The edges of war. Cape Town: Juta.

NDLETYANA, M. 2008. African intellectuals in 19th and 20th century: South Africa. Cape Town: HSRC.

OPLAND, J. \& NYAMENDE, A., eds. 2008. Isaac Williams Wauchope: selected writings, 1874-1916. Cape Town: Van Riebeeck Society.

PEIRES, J. 1981. The house of Phalo: a history of the Xhosa people in the days of their independence. Johannesburg: Jonathan Ball.

SHEPHERD, R.H.W. s.a. The story of a century: 1841-1941. Lovedale: Lovedale Press.

WILLIAMS, D. 1983. The journal and selected writings of the Reverend Tiyo Soga. Cape Town: Balkema.

\section{Key concepts:}

Cape colony

Glasgow Missionary Society

minute book

missionary logistics

Xhosa intellectuals

\section{Kernbegrippe:}

Glasgow Sending Genootskap

Kaapkolonie

notuleboek

sendinglogistiek

Xhosa-intellektuele 
